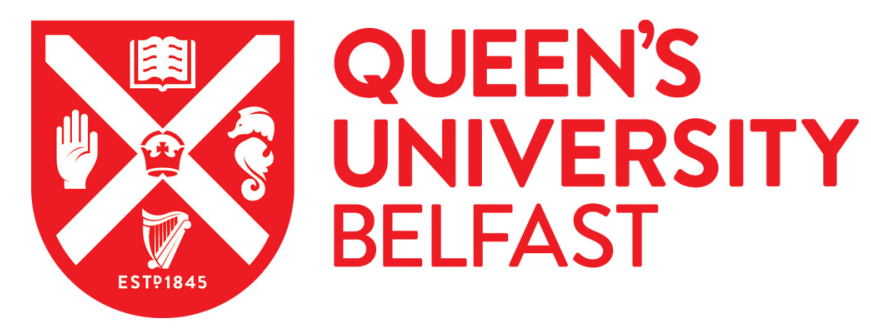

\title{
Influence of the arbuscular mycorrhizal fungus Glomus mosseae on uptake of arsenate by the As hyperaccumulator fern Pteris vittata $L$.
}

Liu, Y., Zhu, Y. G., Chen, B. D., Christie, P., \& Li, X. L. (2005). Influence of the arbuscular mycorrhizal fungus Glomus mosseae on uptake of arsenate by the As hyperaccumulator fern Pteris vittata L. Mycorrhiza, 15(3), 187-192. https://doi.org/10.1007/s00572-004-0320-7

Published in:

Mycorrhiza

Queen's University Belfast - Research Portal:

Link to publication record in Queen's University Belfast Research Portal

\section{General rights}

Copyright for the publications made accessible via the Queen's University Belfast Research Portal is retained by the author(s) and / or other copyright owners and it is a condition of accessing these publications that users recognise and abide by the legal requirements associated with these rights.

Take down policy

The Research Portal is Queen's institutional repository that provides access to Queen's research output. Every effort has been made to ensure that content in the Research Portal does not infringe any person's rights, or applicable UK laws. If you discover content in the Research Portal that you believe breaches copyright or violates any law, please contact openaccess@qub.ac.uk. 
Y. Liu • Y. G. Zhu • B. D. Chen - P. Christie $\cdot$ X. L. Li

\section{Influence of the arbuscular mycorrhizal fungus Glomus mosseae on uptake of arsenate by the As hyperaccumulator fern Pteris vittata L.}

Received: 14 January 2004 / Accepted: 8 July 2004

(C) Springer-Verlag 2004

\begin{abstract}
We report for the first time some effects of colonization by an arbuscular mycorrhizal (AM) fungus (Glomus mosseae) on the biomass and arsenate uptake of an As hyperaccumulator, Pteris vittata. Two arsenic levels $(0$ and $300 \mathrm{mg} \mathrm{As} \mathrm{kg}{ }^{-1}$ ) were applied to an already contaminated soil in pots with two compartments for plant and hyphal growth in a glasshouse experiment. Arsenic application had little or no effect on mycorrhizal colonization, which was about $50 \%$ of root length. Mycorrhizal colonization increased frond dry matter yield, lowered the root/ frond weight ratio, and decreased frond As concentration by $33-38 \%$. Nevertheless, transfer of As to fronds showed a $43 \%$ increase with mycorrhizal colonization at the higher soil As level. Frond As concentrations reached about $1.6 \mathrm{~g} \mathrm{~kg}^{-1}$ (dry matter basis) in non-mycorrhizal plants in the As-amended soil. Mycorrhizal colonization elevated root $\mathrm{P}$ concentration at both soil As levels and mycorrhizal plants had higher $\mathrm{P} / \mathrm{As}$ ratios in both fronds and roots than did non-mycorrhizal controls.
\end{abstract}

Keywords Arsenic Arbuscular mycorrhiza - Arsenic hyperaccumulator $\cdot$ As resistance $\cdot$ Phytoremediation

\footnotetext{
Y. Liu $\cdot$ P. Christie $\cdot$ X. L. Li $(\bowtie)$

Department of Plant Nutrition,

China Agricultural University,

2 Yuanmingyuan Road,

Beijing, 100094, China

e-mail: lixl@cau.edu.cn

Tel.: +86-10-62891325

Fax: +86-10-62891016

Y. G. Zhu • B. D. Chen

Department of Soil Environmental Science,

Research Center for Eco-Environmental Sciences,

Chinese Academy of Sciences,

Beijing , 100085, China

P. Christie

Agricultural and Environmental Science Department,

Queen's University Belfast,

Newforge Lane,

Belfast, BT9 5PX, UK
}

\section{Introduction}

Arsenic is a common element in the Earth's crust, averaging about $3 \mathrm{mg} \mathrm{As} \mathrm{kg}$, and it can be locally abundant from anthropogenic activities such as mining, smelting and other industrial and agricultural activities, or naturally abundant (Mandal and Suzuki 2002; Valberg et al. 1997). Arsenic is regarded as a hazardous material and under certain exposure conditions some forms are toxic and can be carcinogenic (Karim 2000). Environmental contamination by As is a serious threat to human health in many parts of the world (Mandal and Suzuki 2002), and As can enter the human food chain through plants and animals. Soil contamination by As can occur in a wide range of sites (Buchet and Lison 1998).

Phytoremediation of metal-contaminated soils requires plants that accumulate and tolerate high metal concentrations in their aboveground biomass, which can be harvested and disposed of or processed for industry or commerce (Ernst 2000; White 2001). An As hyperaccumulator, the brake fern Pteris vittata, was recently discovered by Ma et al. (2001). The plant is extremely efficient in extracting As from contaminated soil and translocating it to the aboveground parts that can accumulate up to $22.6 \mathrm{~g} \mathrm{~kg}^{-1} \mathrm{As}$ on a dry matter basis in the frond. Furthermore, Zhao et al. (2002) identified three more new species of As hyperaccumulators in the genus Pteris and demonstrated that As hyperaccumulation is a constitutive property in $P$. vittata.

Arbuscular mycorrhizal (AM) fungi are widely distributed in natural and agricultural soils (Smith and Read 1997). Investigations by Turnau (1998) and Gucwa-Przepiora and Turnau (2001) on plants colonizing $\mathrm{Zn}$ wastes in Poland indicate that non-mycorrhizal species may predominate during the initial colonization of contaminated sites and that mycorrhizal species may gradually become more important as ecological succession proceeds. Plants forming mycorrhizas can grow on As-contaminated soils (Meharg and Hartley-Whitaker 2002; Sharples et al. 2000a,b). Mycorrhizal fungi can make an important contribution by obtaining P for their host plants but this may lead to problems on arsenate-contaminated substrates if enhanced acquisition 
of phosphate is accompanied by enhanced acquisition of arsenate. Thus, the role of mycorrhizal associations should be considered when considering the toxicity of As to plants. Most hyperaccumulators are non-mycorrhizal, and there are few reports on the role played by arbuscular mycorrhiza in As hyperaccumulation. Since arsenate can enter plants through their phosphate transporters (Lee 1982), mycorrhizal fungi may enhance uptake of both phosphate and arsenate by plants. Wang et al. (2002) have investigated interactions between arsenate and phosphate and the uptake and distribution of As and $\mathrm{P}$ in the As hyperaccumulator $P$. vittata.

Engineering effective hyperaccumulation of As depends upon using plants that are highly tolerant to As so as to accumulate significant biomass and that have the capacity to store more As aboveground (Baker et al. 1999). Dhankher et al. (2002) have developed a genetically based phytoremediation strategy for As in which the oxyanion arsenate is transported aboveground. We suggest a mycorrhizabased phytoremediation strategy for As in which mycorrhiza can assist the host hyperaccumulator to increase its biomass and transfer more As into the aboveground parts. The role of AM fungi in arsenate resistance of the grass Holcus lanatus has been investigated by Gonzalez-Chavez et al. (2002). However, as far as we know there is no published information on the role of mycorrhiza in the uptake of As by As hyperaccumulators. The objectives of the present study were therefore to investigate whether or not the As hyperaccumulator $P$. vittata can form an arbuscular mycorrhizal association with the AM fungus Glomus mosseae, and if so, whether or not mycorrhizal colonization can influence plant biomass and As uptake from As-contaminated soil.

\section{Materials and methods}

\section{Experimental conditions}

The Plexiglas pots used had two compartments separated by a 30- $\mu \mathrm{m}$ mesh size nylon net that allowed penetration by hyphae but not by roots. Both compartments were of equal volume, one for plant growth and the other for hyphal growth. The pots were $15 \mathrm{~cm}$ high, $10 \mathrm{~cm}$ deep and $10 \mathrm{~cm}$ wide. The experiment consisted of a randomized block design with two factors: mycorrhizal treatment (non-mycorrhizal and inoculated with $G$. mosseae) and As addition level of 0 and $300 \mathrm{mg} \mathrm{kg}^{-1}$ in the form of $\mathrm{Na}_{3} \mathrm{AsO}_{4} \cdot 12 \mathrm{H}_{2} \mathrm{O}$ ( $\mathrm{Tu}$ and $\mathrm{Ma}$ 2002). There were therefore four treatments with three replicates, giving a total of 12 pots.

The experimental soil was an As-contaminated soil collected from a field located at Chenzhou city, Hunan province $\left(25^{\circ} 35^{\prime} \mathrm{N}, 113^{\circ} 00^{\prime} \mathrm{E}\right)$. The soil had the following properties: $\mathrm{pH} 8.03$ (soil:water ratio, 1:2.5), organic matter content $5.25 \%, \mathrm{NaHCO}_{3}$-extractable P $13.0 \mathrm{mg} \mathrm{kg}^{-1}$ (water: soil ratio, 20:1; extraction for $30 \mathrm{~min}$; ICP-OES), total As $95.9 \mathrm{mg} \mathrm{kg}{ }^{-1}\left(\mathrm{HNO}_{3}-\mathrm{HCLO}_{4}\right.$ digest; atomic fluorescence spectrometry), $\mathrm{NaHCO}_{3}$-extractable As $4.54 \mathrm{mg} \mathrm{kg}^{-1}$ (water: soil ratio, 20:1; extraction for $30 \mathrm{~min}$; atomic fluorescence spectrometry). The soil was passed through a $2-\mathrm{mm}$ sieve, sterilized by autoclaving at $120^{\circ} \mathrm{C}$ for $2 \mathrm{~h}$, and air-dried. All treatments received mineral nutrients added to the soil as basal fertilizers at rates of $200 \mathrm{mg} \mathrm{kg}^{-1} \mathrm{~N}\left(\mathrm{NH}_{4} \mathrm{NO}_{3}\right)$, $30 \mathrm{mg} \mathrm{kg}^{-1} \mathrm{P}\left(\mathrm{CaHPO}_{4} \cdot 2 \mathrm{H}_{2} \mathrm{O}\right)$ and $150 \mathrm{mg} \mathrm{kg}^{-1} \mathrm{~K}\left(\mathrm{~K}_{2} \mathrm{SO}_{4}\right)$. The soil was incubated for 3 weeks after addition of $\mathrm{Na}_{3} \mathrm{AsO}_{4} \cdot 12 \mathrm{H}_{2} \mathrm{O}$ to allow equilibration of the added As. Aliquots (650 and $700 \mathrm{~g})$ of soil were placed in the plant and hyphal compartments.

The AM fungus G. mosseae BEG167 was propagated on maize for 10 weeks. The growth medium containing spores together with infected maize root fragments was used as inoculum. Inoculum $(50 \mathrm{~g})$ was mixed with the soil of the plant compartment to produce mycorrhizal treatments, and $50 \mathrm{~g}$ sterilized inoculum plus $25 \mathrm{ml}$ mycorrhizal fungal-free filtrate from the inoculum suspension were added to produce the non-mycorrhizal treatments in order to provide a similar microflora except for the mycorrhizal fungus.

Seedlings of Chinese brake fern ( $P$. vittata L.) were raised from spores in sterilized soil and vermiculite $(2: 1 \mathrm{v} / \mathrm{v})$ in 3-1 plastic pots. After germination, when the seedlings had grown to a height of $1 \mathrm{~cm}$, they were transplanted into seed trays. When the young ferns had two fronds and were $2 \mathrm{~cm}$ in height, they were transplanted into the plant compartments of the experimental Plexiglas pots.

The experiment was conducted from April to July in 2003 in a growth chamber at a temperature of $22-25^{\circ} \mathrm{C}$ and with a photoperiod of $14 \mathrm{~h}$ using supplementary lighting. Deionized water was used daily to adjust soil moisture to about $15 \%(\mathrm{w} / \mathrm{w})$.

\section{Harvest and analysis}

Fronds and roots of $P$. vittata were harvested separately after growth for 15 weeks. Samples were rinsed twice with deionized water. Fresh portions of the root samples were retained for determination of mycorrhizal colonization. The dry weights of the fronds and the remaining roots were determined after drying in an oven at $70^{\circ} \mathrm{C}$ for $48 \mathrm{~h}$. Subsamples after oven drying were digested using a microwave accelerated reaction system (CEM Corporation). A subsample of about $200 \mathrm{mg}$ was accurately weighed into a PTFE pressure vessel and $5 \mathrm{ml}$ concentrated $\mathrm{HNO}_{3}$ was added. The microwave digestion program settings were as follows: power $1,200 \mathrm{~W}$, temperature $160^{\circ} \mathrm{C}$, pressure $350 \times 10^{5} \mathrm{~Pa}$, and holding time $15 \mathrm{~min}$. After cooling, the sample solution was transferred with deionized water and filtered into a $50 \mathrm{ml}$ plastic bottle. The As concentration was determined using an atomic fluorescence spectrometer (Model AF610A, Beijing Rayleigh Analytical Instrument, China) and the $\mathrm{P}$ concentration was determined colorimetrically on a spectrophotometer using the standard vanadium-molybdenum yellow method.

After harvest, the soil from the hyphal compartments was cut with a knife into one inner slice $1 \mathrm{~cm}$ thick and two outer slices, each $2 \mathrm{~cm}$ thick and these were sieved $(<1 \mathrm{~mm})$ prior to analysis. Soil $\mathrm{pH}$ was measured with a potentiometer (Thermo Orion Model 868) at a 1:2.5 soil-to-water ratio. 


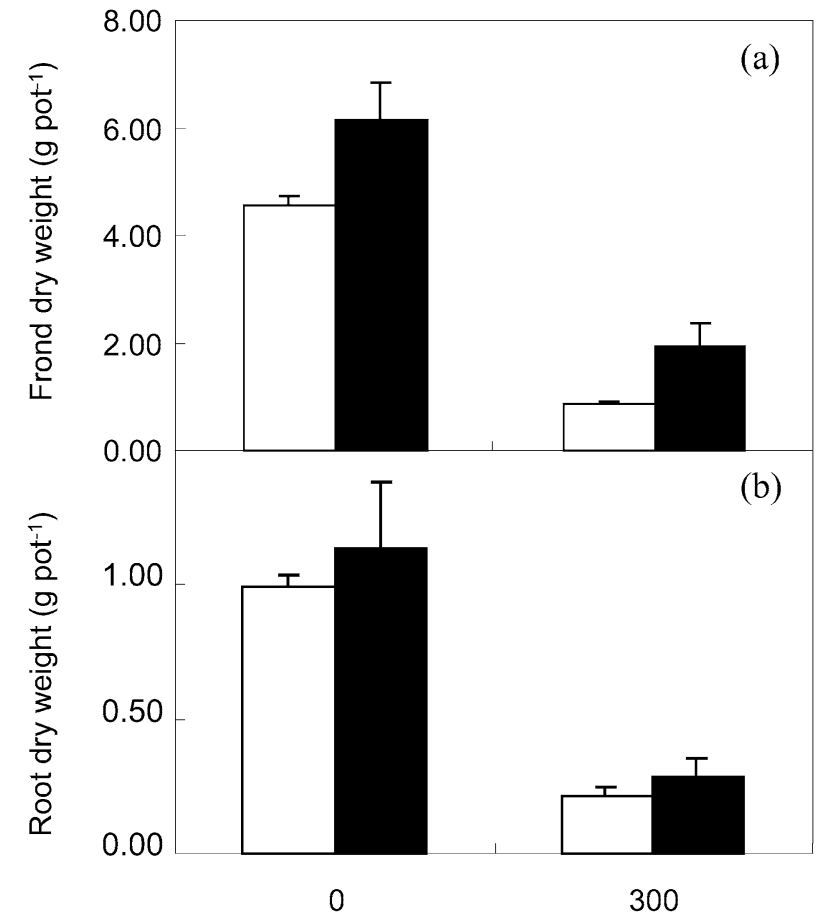

As addition level $\left(\mathrm{mg} \mathrm{kg}^{-1}\right)$

Fig. 1 Frond (a) and root (b) dry weight of Pteris vittata at As addition levels of 0 and $300 \mathrm{mg} \mathrm{kg}^{-1}$. Open bars Non-mycorrhizal, closed bars mycorrhizal. Error bars $1 \mathrm{SE}$

Because As is chemically similar to P, the same chemical extractant has been employed to determine the available fractions of the two elements in soil (Gruebel et al. 1988; Johnson and Barnard 1979; Rodriguez et al. 2003). Soil available $\mathrm{As}$ and $\mathrm{P}$ were therefore both extracted with $0.5 \mathrm{~mol} \mathrm{l}^{-1} \mathrm{NaHCO}_{3}$ (pH 8.5; water: soil ratio, 20:1; extraction for $30 \mathrm{~min}$ ). Available As was determined with an atomic fluorescence spectrometer (described above) and $\mathrm{P}$ by inductively coupled plasma-optical emission spectrometry using a Perkin-Elmer Optima 2000 ICP-OES unit.

Mycorrhizal colonization was estimated on randomly selected root segments. Root samples were cut into $1-\mathrm{cm}-$ long bundles, cleared in $10 \%(\mathrm{w} / \mathrm{v}) \mathrm{KOH}$ at $90^{\circ} \mathrm{C}$ for 12 15 min in a water bath, rinsed three times and then stained with Trypan Blue at $90^{\circ} \mathrm{C}$ for 3-5 min, stored in glycerine and measured by the gridline-intersect method (Giovannetti and Mosse 1980).

\section{Results}

No root colonization was observed in the uninoculated plants. Inoculated plants had about $50 \%$ of their root length colonized by the AM fungus irrespective of As addition to the soil, indicating that $G$. mosseae BEG167 was capable of root colonization at the As levels used in the experiment. Biomass of $P$. vittata decreased markedly at the elevated As addition level of $300 \mathrm{mg} \mathrm{kg}^{-1}$ (Fig. 1). Mycorrhizal colonization significantly increased frond dry weight at both As levels, while no difference was found in root dry weight. The frond dry weight of mycorrhizal plants increased by $34 \%$ and $125 \%$ at the two As addition treatments compared with the non-mycorrhizal controls. Accordingly, the root/ frond ratio was lower in mycorrhizal plants, by about $17 \%$ with no added As and by about $41 \%$ with $300 \mathrm{mg}$ added As $\mathrm{kg}^{-1}$.

Arsenic concentrations in fronds and roots of both the non-mycorrhizal and mycorrhizal plants increased dramatically as As addition levels increased (Fig. 2a, b). The highest As concentration approached $1.6 \mathrm{~g} \mathrm{As} \mathrm{kg}^{-1}$ in the fronds of non-mycorrhizal plants at the higher soil As level and the frond As concentration was 3-10 times that of the root As concentration under these conditions. At both soil As levels, frond As concentration was depressed by 33-
Fig. 2 Frond (a) and root (b) As concentrations and frond (c) and root (d) $\mathrm{P}$ concentrations of $P$. vittata at As addition levels of 0 and $300 \mathrm{mg} \mathrm{kg}^{-1}$. Open bars Non-mycorrhizal, closed bars mycorrhizal. Error bars $1 \mathrm{SE}$
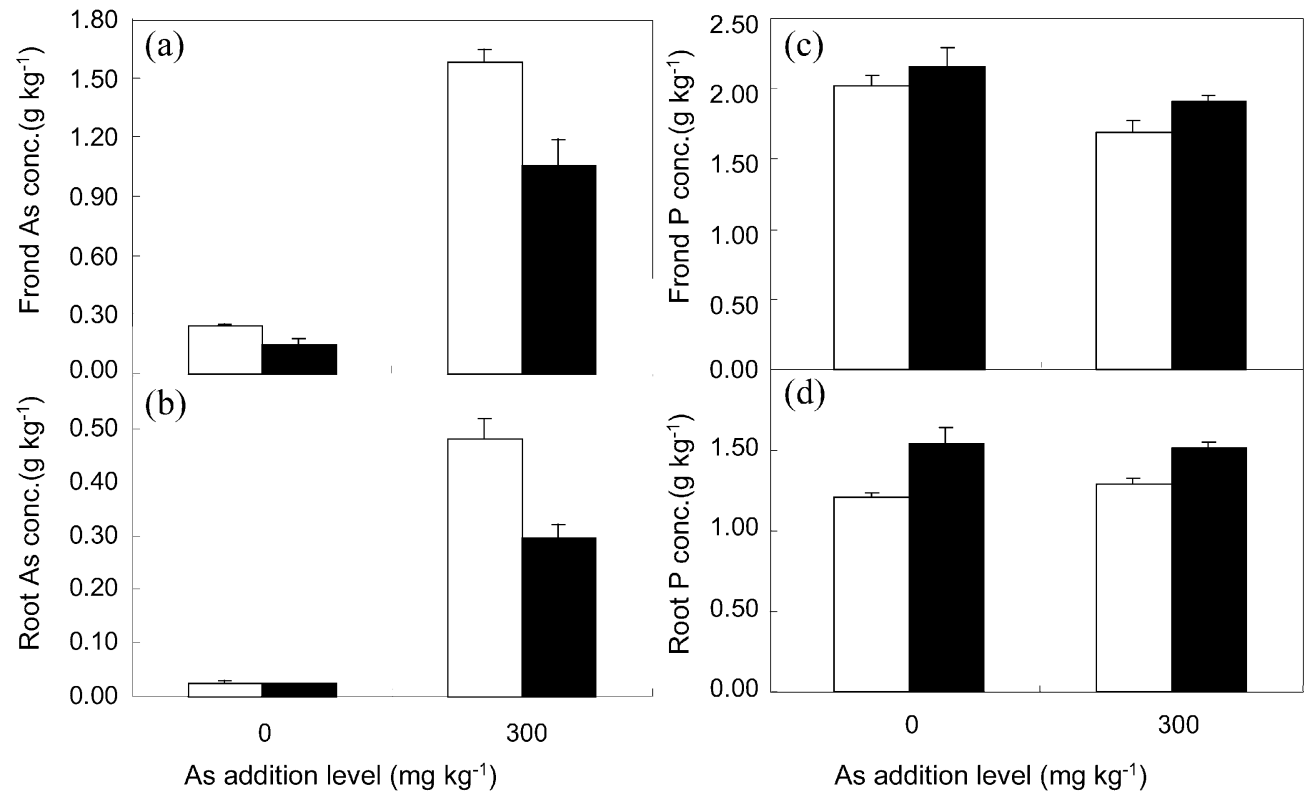
Fig. 3 Frond (a) and root (b) As contents and frond (c) and root (d) $\mathrm{P}$ contents of $P$. vittata at As addition levels of 0 and $300 \mathrm{mg}$ $\mathrm{kg}^{-1}$. Open bars Non-mycorrhizal, closed bars mycorrhizal. Error bars $1 \mathrm{SE}$
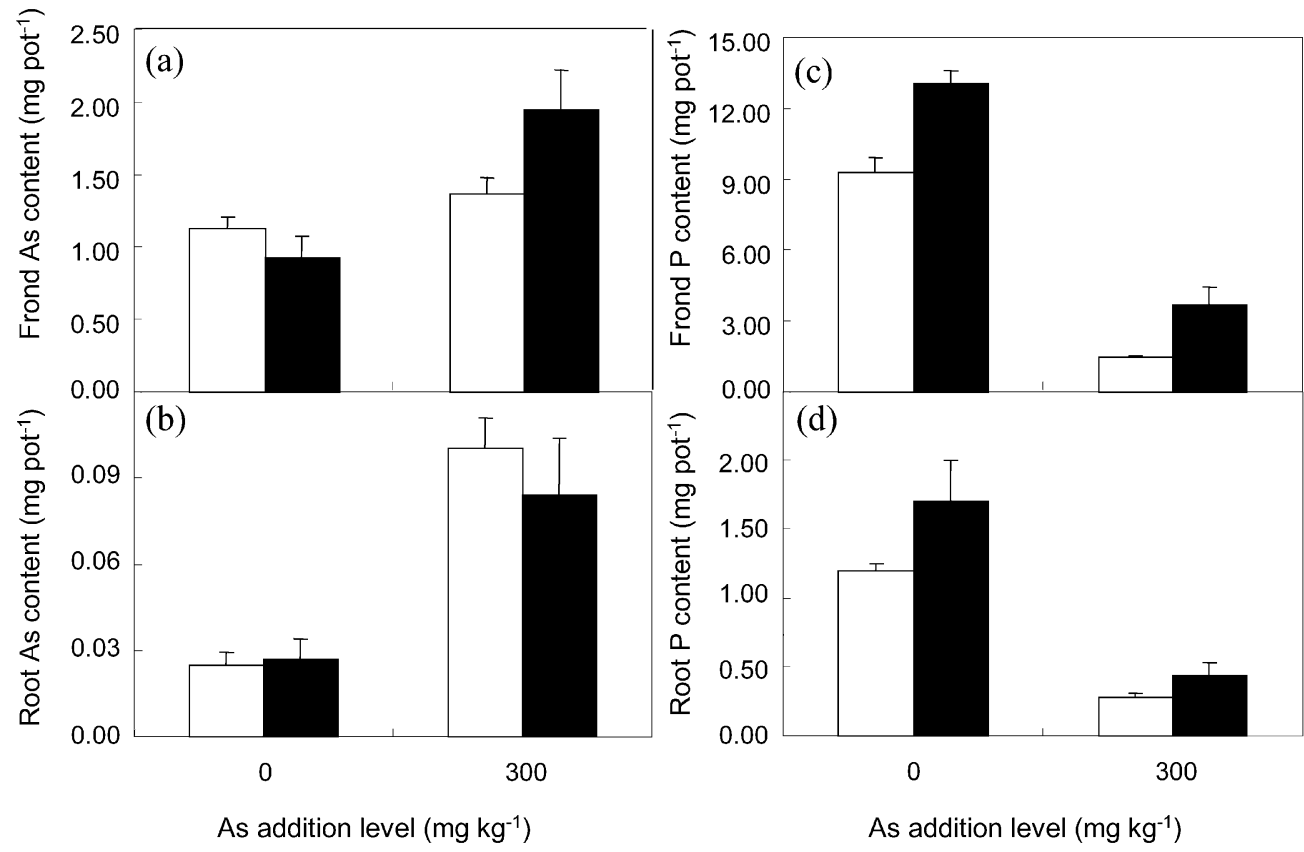

$38 \%$ by mycorrhizal colonization and a similar trend was found for root As concentration at the As addition level of $300 \mathrm{mg} \mathrm{kg}^{-1}$.

Frond $\mathrm{P}$ concentration was about $2 \mathrm{~g} \mathrm{~kg}^{-1}$ and root $\mathrm{P}$ concentration about $1.4 \mathrm{~g} \mathrm{~kg}^{-1}$, presumably sufficient for adequate growth of the host plants under the experimental conditions since no symptoms of $\mathrm{P}$ deficiency were observed. Application of As significantly decreased frond $\mathrm{P}$ concentration of both inoculation treatments but had little effect on root P concentration (Fig. 2c, d). No significant difference in frond $\mathrm{P}$ concentration was recorded between mycorrhizal and non-mycorrhizal plants at either soil As level. However, the root P concentration in mycorrhizal plants was higher than in non-mycorrhizal controls.

Mycorrhizal colonization significantly increased the As content of the fronds by $43 \%$ at the $300 \mathrm{mg} \mathrm{kg}^{-1}$ addition level to soil, while there was no obvious influence when no As was added (Fig. 3a, b). Root As content was unaffected by mycorrhizal colonization. Phosphorus contents of both the non-mycorrhizal and mycorrhizal plants decreased dramatically as the As addition level increased (Fig. 3c, d). When no As was added, frond and root P contents were significantly increased (by $29 \%$ ) by mycorrhizal colonization. With $300 \mathrm{mg} \mathrm{kg}^{-1}$ added As, frond $\mathrm{P}$ content was

Table 1 Frond/root As and $\mathrm{P}$ content and frond and root $\mathrm{P} / \mathrm{As}$ ratios of Pteris vittata at As addition levels of 0 and $300 \mathrm{mg} \mathrm{kg}^{-1}$. Means \pm SE. $-M$ Non-mycorrhizal, $+M$ mycorrhizal

\begin{tabular}{lllrl}
\hline Treatment & $\begin{array}{l}\text { Frond/root As } \\
\text { content }\end{array}$ & $\begin{array}{l}\text { Frond/root } \mathrm{P} \\
\text { content }\end{array}$ & \multicolumn{1}{l}{$\begin{array}{l}\text { Frond } \mathrm{P} / \mathrm{As} \\
\text { content }\end{array}$} & $\begin{array}{l}\text { Root P/As } \\
\text { content }\end{array}$ \\
\hline $\mathrm{As}_{0}-\mathrm{M}$ & $49.75 \pm 11.75$ & $7.77 \pm 0.60$ & $8.27 \pm 0.10$ & $52.04 \pm 9.65$ \\
$\mathrm{As}_{0}+\mathrm{M}$ & $36.54 \pm 4.72$ & $8.01 \pm 1.09$ & $15.14 \pm 2.84$ & $67.81 \pm 8.61$ \\
$\mathrm{As}_{300}-\mathrm{M}$ & $13.67 \pm 0.78$ & $5.47 \pm 0.54$ & $1.07 \pm 0.05$ & $2.71 \pm 0.18$ \\
$\mathrm{As}_{300}+\mathrm{M}$ & $24.68 \pm 3.15$ & $8.62 \pm 0.34$ & $1.85 \pm 0.19$ & $5.19 \pm 0.32$ \\
\hline
\end{tabular}

increased by $60 \%$ by mycorrhizal colonization, and root $\mathrm{P}$ content by $37 \%$.

Mycorrhizal colonization significantly elevated the transfer of As and $\mathrm{P}$ to fronds at $300 \mathrm{mg} \mathrm{kg}^{-1}$ added $\mathrm{As}$ (Table 1). Frond and root P/As ratios all decreased as As application increased. Mycorrhizal plants had higher P/ As ratios than non-mycorrhizal controls, especially in the fronds.

At harvest, the residual soil $\mathrm{pH}$ values in the plant compartments of inoculated treatments were higher than in the corresponding uninoculated controls (data not shown). There were similar trends in the 0-1 cm layer of the hyphal compartments at the $300 \mathrm{mg} \mathrm{kg}^{-1}$ As application rate. Both soil-available As and P increased significantly in both inoculation treatments with the elevated As addition level (data not shown). However, $\mathrm{NaHCO}_{3}$-extractable As concentrations in the soil did not differ between mycorrhizal treatments and non-mycorrhizal controls.

\section{Discussion}

Mycorrhizal colonization of $P$. vittata by G. mosseae did not appear to be inhibited by As application. However, As application greatly decreased the biomass of the fern (Fig. 1). High concentrations of As inhibited the growth of the ericoid mycorrhizal fungus Hymenoscyphus ericae (Sharples et al. 1999). In the present experiment, however, we did not find any significant inhibition of mycorrhizal colonization by $G$. mosseae when arsenate was added to the soil at the rate of $300 \mathrm{mg} \mathrm{As} \mathrm{kg}^{-1}$. This may imply that As had little or no effect on spore germination or AM colonization by $G$. mosseae $\mathrm{BEG} 167$, an isolate that did not originate from Ascontaminated soil. Although root growth was unaffected by mycorrhizal colonization, plant P concentration was ele- 
vated and this may be a factor conferring enhanced tolerance of mycorrhizal plants to As (Fig. 2c, d).

Arsenate is assumed to be taken up by plant roots by the same transport system across membranes as phosphate (Meharg et al. 1994; Sharples et al. 1999). This indicates that As-P relationships could play some role in the detoxification of environmental arsenate in mycorrhizal systems (Benson et al. 1981). In the present work, inoculation with the AM fungus led to a decrease in the As concentration in the host plants (Fig. 2a, b) and an increase in dry matter yield, especially of the fronds (Fig. 1). Although the As concentrations in the fronds were lower at the high As application rate, inoculated treatments had higher biomass, giving larger amounts of As uptake by the fronds of mycorrhizal plants (Fig. 3a, b). The effects of AM fungi on plant uptake of metals are not clear (Leyval et al. 1997). At the high As application rate $\left(300 \mathrm{mg} \mathrm{kg}^{-1}\right)$, the increase in biomass with mycorrhizal inoculation was so pronounced that As content was still $28 \%$ higher in mycorrhizal plants even when the As concentration was lowered by $38 \%$. The enhanced biomass with mycorrhizal inoculation was associated with enhanced P uptake. Depletion of P in the hyphal compartment of inoculated treatments compared with the uninoculated controls (data not shown) suggests the occurrence of $\mathrm{P}$ transfer from the hyphal compartment to the roots by hyphae and enhanced plant $\mathrm{P}$ nutrition.

Arsenic resistance of mycorrhizal plants might be partly explained by the higher P/As ratios in mycorrhizal plants. Thus, mycorrhizal plants obtained more $\mathrm{P}$ than non-mycorrhizal controls (Table 1), and the higher $\mathrm{P} / \mathrm{As}$ ratios may be one of the mechanisms by which AM fungi can enhance host plant resistance to arsenic, even in the case of As hyperaccumulators. Many studies have indicated that positive effects of mycorrhizas on host plants under environmental stresses could be directly or indirectly attributed to improved plant phosphorus nutrition. The absence of any significant difference in frond $\mathrm{P}$ concentration between mycorrhizal and non-mycorrhizal plants in the present work indicates that frond $\mathrm{P}$ status was unaffected by mycorrhizal colonization. However, there were significant increases in root $P$ concentration with mycorrhizal colonization. In general, the phosphate analogue arsenate is more toxic to plants than arsenite. On the other hand, arsenate reductase, which catalyzes the reduction of arsenate to arsenite, is expressed in leaves only and not in roots (Dhankher et al. 2002). Since more $\mathrm{P}$ was stored in the roots with increasing As application, and mycorrhizal colonization enhanced this trend, we suggest that the higher $\mathrm{P}$ concentration in the roots may have contributed to As resistance in the mycorrhizal plants. Phytotoxicity of arsenate has been observed under conditions of low P supply (Wang et al. 2002), and mycorrhizal inoculation has been observed to alleviate As phytotoxicity by increasing plant $\mathrm{P}$ content.

The As depletion near the root surface indicates low mobility of As in the soil similar to that of P. The relatively higher As concentration in the root compartment soil may have been derived from mobilization of immobile fractions of soil As by a mycorrhizosphere effect. We also observed higher soil $\mathrm{pH}$ values in the plant and hyphal compartments of mycorrhizal plants compared with non-mycorrhizal controls, especially at the high As application rate, and this may have resulted in higher As solubility.

Our results indicate positive effects of mycorrhiza on plant growth under high soil As conditions. When plants were mycorrhizal, lower root/frond dry weight ratio and higher frond/root As contents indicated enhanced aboveground biomass and As uptake by fronds of $P$. vittata, and this could assist the hyperaccumulator to remove more As from the soil. Some studies have found the opposite trend of restricted translocation of As from the soil to the aboveground plant biomass following inoculation with AM fungi (Meharg et al. 1994; Sidibe and Tesarova 2001). In conclusion, the AM fungus $G$. mosseae formed a stable association with Chinese brake fern (P. vittata L.) and possessed substantial resistance to As toxicity. Mycorrhizal colonization increased plant biomass and consequently increased the quantity of As removed from the soil by the hyperaccumulator.

Acknowledgements This work was funded by the Natural Science Foundation of China (Project 30370818), the National High Technology Research and Development Program (863 Program) of the Science Technology Department of the People's Republic of China (Project 2001AA645010-4) and the Royal Society of London (Project 15360). The original seedlings were kindly supplied by Dr. Tongbin Chen of the Institute of Geographical Sciences and Natural Resources Research, Chinese Academy of Sciences.

\section{References}

Baker AJM, McGrath SP, Reeves RD, Smith JAC (1999) Metal hyperaccumulator plants: a review of the ecology and physiology of a biochemical resource for phytoremediation of metalpolluted soils. In: Terry N, Bañuelos GS (eds) Phytoremediation of contaminated soil and water. Lewis, Boca Raton, Fla., pp 85 107

Benson AA, Cooney RV, Herrera-Lasso LJM (1981) Arsenic metabolism in algae and higher plants. J Plant Nutr 3:285-292

Buchet JP, Lison D (1998) Mortality by cancer in groups of the Belgian population with a moderately increased intake of arsenic. Int Arch Occup Environ Health 71:125-130

Dhankher OP, Li YJ, Rosen BP, Shi J, Salt D, Senecoff JF, Sashti NA, Meagher RB (2002) Engineering tolerance and hyperaccumulation of arsenic in plants by combining arsenate reductase and $\gamma$ glutamylcysteine synthetase expression. Nat Biotechnol 20: $1140-1145$

Ernst WHO (2000) Evolution of metal hyperaccumulation and phytoremediation hype. New Phytol 146:357-358

Giovannetti M, Mosse B (1980) An evaluation of techniques for measuring vesicular-arbuscular infection in roots. New Phytol $84: 489-500$

Gonzalez-Chavez C, Harris PJ, Dodd J, Meharg AA (2002) Arbuscular mycorrhizal fungi confer enhanced arsenate resistance on Holcus lanatus. New Phytol 155:163-171

Gruebel KA, Davis JA, Leckie JO (1988) The feasibility of using sequential extraction techniques for arsenic and selenium in soils and sediments. Soil Sci Soc Am J 52:390-397

Gucwa-Przepiora E, Turnau K (2001) Arbuscular mycorrhiza and plant succession on zinc smelter spoil heap in Katowice-Welnowiec. Acta Soc Bot Pol 70:153-158

Johnson SE, Barnard WM (1979) Comparative effectiveness of fourteen solutions for extracting arsenic from four western New York soils. Soil Sci Soc Am J 43:304-308

Karim MM (2000) Arsenic in groundwater and health problems in Bangladesh. Water Res 34:304-310 
Lee RB (1982) Selectivity and kinetics of ion uptake by barley plants following nutrient deficiency. Ann Bot 50:429-449

Leyval C, Turnau K, Haselwandter K (1997) Effect of heavy metal pollution on mycorrhizal colonization and function: physiological, ecological and applied aspects. Mycorrhiza 7:139-153

Ma LQ, Komar KM, Tu C, Zhang WH, Cai Y, Kennelley ED (2001) A fern that hyperaccumulates arsenic. Nature 409:579

Mandal BK, Suzuki KT (2002) Arsenic round the world: a review. Talanta 58:201-235

Meharg AA, Hartley-Whitaker J (2002) Arsenic uptake and metabolism in arsenic resistant and nonresistant plant species. New Phytol 154:29-43

Meharg AA, Bailey J, Breadmore K, MacNair MR (1994) Biomass allocation, phosphorus nutrition and vesicular-arbuscular mycorrhizal infection in clones of Yorkshire Fog, Holcus lanatus L. (Poaceae) that differ in their phosphate uptake kinetics and tolerance to arsenate. Plant Soil 160:11-20

Rodriguez RR, Basta NT, Casteel SW, Armstrong FP, Ward DC (2003) Chemical extraction methods to assess bioavailable arsenic in soil and solid media. J Environ Qual 32:876-884

Sharples JM, Meharg AA, Chambers SM, Cairney JWG (1999) Arsenate sensitivity in ericoid and ectomycorrhizal fungi. Environ Toxicol Chem 18:1848-1855

Sharples JM, Meharg AA, Chambers SM, Cairney JWG (2000a) Mechanism of arsenate resistance in the ericoid mycorrhizal fungus Hymenoscyphus ericae. Plant Physiol 124:1327-1334
Sharples JM, Meharg AA, Chambers SM, Cairney JWG (2000b) Evolution-symbiotic solution to arsenic contamination. Nature 404:951-952

Sidibe A, Tesarova M (2001) Effect of inoculation with endomycorrhizal fungi on the growth of selected plants. Acta Univ Agric Silvic Mendelianae Brunensis 49:15-20

Smith SE, Read DJ (1997) Mycorrhizal symbiosis, 2nd edn. Academic Press, London

Tu C, Ma LQ (2002) Effects of arsenic concentrations and forms on arsenic uptake by the hyperaccumulator ladder brake. J Environ Qual 31:641-647

Turnau K (1998) Heavy metal content and localization in mycorrhizal Euphorbia cyparissias from zinc wastes in southern Poland. Acta Soc Bot Pol 67:105-113

Valberg PA, Beck BD, Bowers TS, Keating JL, Bergstrom PD, Boardman PD (1997) Issues in setting health-based cleanup levels for arsenic in soil. Regul Toxicol Pharm 26:219-229

Wang JR, Zhao FJ, Meharg AA, Raab A, Feldmann J, McGrath SP (2002) Mechanism of arsenic hyperaccumulation in Pteris vittata. Uptake kinetics, interactions with phosphate, and arsenic speciation. Plant Physiol 130:1552-1561

White PJ (2001) Phytoremediation assisted by microorganisms. Trends Plant Sci 6:502-502

Zhao FJ, Dunham SJ, McGrath SP (2002) Arsenic hyperaccumulation by different fern species. New Phytol 156:27-31 